\title{
Young Scientist Pioneer 2019: Evaluation of the Effectiveness of Program at SMK Wira Penrissen, Sarawak
}

\author{
Amalina Yusup ${ }^{1 *}$ Asraful Syifaa' Ahmad ${ }^{2}$ Rafidah Muhamad ${ }^{2}$ Nabilah Kassim³ \\ Fathiah Nabila Mohd Daud ${ }^{4}$, Nurazrin Mohd Esa ${ }^{2}$, Liza Md Salleh ${ }^{5}$, D. Dahyuna \\ Mohd Yunos ${ }^{5}$, Nursyazwani Aznan ${ }^{6}$, Rafidah Abd Rahim 6 , Mohd Iskandar Ishak \\ Filzah Hazirah Jaffar ${ }^{5}$, Nurlaila Syamsul Bahri ${ }^{5}$, Nurul Diyana Zainal ${ }^{3}$, Muhamad \\ Farhin Harun ${ }^{2}$, Sarah Alia Norazlan ${ }^{1}$
}

\author{
${ }^{1}$ Faculty of Built Environment \& Surveying, Universiti Teknologi Malaysia \\ ${ }^{2}$ School of Computing, Faculty of Engineering, Universiti Teknologi Malaysia \\ ${ }^{3}$ Department of Physics, Faculty of Science, Universiti Teknologi Malaysia \\ ${ }^{4}$ Azman Hashim International Business School, Universiti Teknologi Malaysia \\ ${ }^{5}$ School of Chemical and Energy Engineering, Universiti Teknologi Malaysia \\ ${ }^{6}$ Deputy Vice Chancellor's Office (Research And Innovation), Universiti Teknologi Malaysia \\ ${ }^{7}$ Deputy Vice Chancellor's Office (Student Affairs) Universiti Teknologi Malaysia \\ ${ }^{*}$ Corresponding author. Email: asrafulsyifaa.ahmad@gmail.com
}

\begin{abstract}
Science, technology, engineering and math (STEM) is a new subject module to prepare the students with high skills demanded by the industry based on Malaysian Education Blueprint 2013-2025. The purpose of this study is to review and analyses the effectiveness of the program done in SMK Wira Penrissen, Kota Samarahan, Sarawak that been held in July 2019. The aim of the program is to attract the students to learn STEM according to the syllabus in a fun way. The items reviewed were in terms of the overall program, the objectives, the activities and also the facilitators. This program was attended by 100 Form One students meanwhile the facilitators were the students from multiple backgrounds of study from Universiti Teknologi Malaysia (UTM). The results show that student satisfaction was increasing gradually for best-managed modules indicating that proactive implementation of appropriate responses to student feedback on their learning journey is effective in improving both student satisfaction and learning.

Keywords: Science, Technology, Engineering, Mathematics, Education
\end{abstract}

\section{INTRODUCTION}

Science, Technology, Engineering and Mathematics (STEM) is an educational program developed to prepare primary and secondary students for college and graduate study in the fields of science, technology, engineering and mathematics (STEM). During the 21st century, workforcerelated to science, technology, engineering, and mathematics (STEM) fields have become increasingly important [1][8][13]. Many countries have integrated STEM education into the school curriculum providing a meaningful learning environment. However, refers to STAR papers on Sunday (17 Mar 2019), the number of students taking the STEM subject is dropping yearly as only $44 \%$ of students in 2018 compared to $48 \%$ in 2012.
Nowadays, STEM education is a concern as stated by [10], STEM education is a critical tool for improving students. Parallel to the industrial revolution 4.0 (IR 4.0), the government is committed to prepare the STEM workers to be ready for the challenge in the global talent pool. Thus, the government has given support by developing a pedagogical with a focus on the key principles to teach the subject effectively starting from secondary school. This STEM education widely spread especially in Sarawak as this activity is fully supported by the state minister.

According to Bernama (2017), Abang Johari stated that they want the setting up of the labs to raise awareness concerning STEM in the rural areas in Sarawak which would encourage the modernization of farming. It needs to implement in more schools statewide to promote the "fun" side of the stream and encourage students to take the 
subjects. Recently, Kolej Datin Seri Endon (KDSE), Universiti Teknologi Malaysia (UTM) has organized a Young Scientist Pioneer Program at SMK Wira Penrissen, Kota Samarahan, Sarawak. The program has been held from 16th to 18th July 2019. There were about 100 students and 16 facilitators participated in the program. The program has collaborated with the Malaysian Optical Association, Faculty of Science, UTM, and Universiti Malaysia Sarawak (UNIMAS). The facilitators were students from different backgrounds of studies in UTM. Hopefully, this uniqueness would make it different from other STEM programs because the sharing ideas from other fields of study would create creative modules. This Young Scientist Pioneer Program was the first and third rebranding program which was conducted under the name of School Attack which has been held at SMK Parit Yusuf, Batu Pahat and SMK Sri Skudai, Skudai, Johor.

This program aims to attract and expose the secondary students to STEM so that they could choose the pure science stream as their top choice at the upper-secondary level as well as university level. The STEM program was accordingly based on the Malaysian Education Development Plan 2013-2025 for the provision of highly skilled workers in line with industry demands. Through this program, the committee is eager to work with schools, universities, government as well as private agencies to tackle the STEM gap independently. While the committee did their brainstorming to merge some resources, ideas and energy, they have relatively driven much more sustainable change by developing a more systematic approach that created an assortment of initiatives focusing on different STEM aspects and interests. The committee was working to create a joint national strategy to invest federal funds in STEM education by increasing public and youth STEM engagement. It is important to improve the STEM experience to reach a demographic in STEM fields yet proposing better graduate education for the STEM workforce.

Therefore, this paper is focusing on the evaluation of the effectiveness of the program at SMK Wira Penrissen, Sarawak. First, the previous study is reviewed to build the module and the result is analyzed in the next section. The evaluation would come from the pre and post questionnaire based on the STEM module prepared. Besides, the interview and facilitator overview also would be considered in this study.

\section{LITERATURE REVIEW}

\subsection{Science, Technology, Engineering and Mathematics (STEM)}

STEM is a curriculum-based to educate a student in four specific disciplines which are science, technology, engineering and mathematics with an applied approach. STEM integrates the subjects into a cohesive learning paradigm based on real-world application [5]. STEM is used to understand the students' misconceptions and the best way to address them. Besides, STEM could also work by teaching science through stories, for example, from Charlie and the Chocolate Factory to The Gruffalo. These children's stories were providing a great context for learning science. Consequently, it might seem simple, but, the assessment for the secondary students' perceptions is needed to value the STEM achievement in school [9].

Based on the Obama administration 2009, "Educate to Innovate" campaign, they were urged to motivate and inspire the students to excel in STEM subjects while addressing an inadequately skilled teacher to educate in these subjects. Their goal is to upgrade the American students from the middle of the pack to the international arena ("Achieving a Sustainable STEM Workforce,"). Hence, the learning module needs to be designed with inspiring wide range flexibility to accommodate different student interest [3].

Meanwhile, in Malaysia, the statistic shows that there was only $23 \%$ of high school students studied pure science. According to the estimates, Malaysia would need to produce at least 5,000 graduates of Science, Technology, Engineering and Mathematics to reach the top 20 countries in the economy, social development and innovation sectors [7]. Therefore, the teachers and leaders need to explore programs and resources to support professional development and drive the impact of teaching across schools and colleges [2]. Thus, the Malaysian Education Curriculum needs to be changed into an interdisciplinary approach called STEM in order to achieve the Malaysian 21st-century skills [12]. The research trends indicate that the STEM education is more focused on university graduates which emphasis in technology and engineering fields is well established conversely less emphasis on the school level [6].

Due to this concern, it is highly needed for the government to develop an outstanding primary science curriculum. This is because different approaches are needed to identify learners' thinking, clarify learning goals to look into students' understanding, both in and between lessons. The curriculum and assessment should not traditionally teach in the material area, but more to the nature surrounding. Besides, inspiring groups and communities should be developed to discover projects, activities and challenges to engage young people of all ages with the worlds to wonder of STEM subjects and careers. Consequently, this group could share ideas, stories and best practices to attract students' interest in learning STEM. For example, STEM clubs, STEM ambassadors, and STEM enrichment. This activity would allow the student to involve in exploring STEM subjects in innovative and inventive ways outside the curriculum. Therefore, the activity could be a great platform and an enjoyable way to engage with students [11]. 


\section{METHODOLOGY}

\subsection{Research design and sample}

This program employed a pre and post-questionnaires as well as a basic survey towards the effectiveness of the program, modules, and facilitators. The sample comprised of 100 Form One students. All the students from the sample completely answered the survey form. These students consist of 57 females and 43 males. Table 1 shows the distribution of these students in each gender while Table 2 shows the list of modules conducted.

Table 1 Number of students by gender

\begin{tabular}{|c|c|}
\hline Gender & Total \\
\hline Male & 43 \\
\hline Female & 57 \\
\hline
\end{tabular}

\begin{tabular}{|c|c|}
\hline Total & 100 \\
\hline
\end{tabular}

\subsection{Research design and sample}

The questionnaire is divided into two sections, namely, Section A and Section B. Section A contained items on the students' demographic data such as gender. Section B contained 18 items on assessments in STEM-related subjects according to the relevance towards each module being shown to the students. These items are divided into six (6) modules where each module has three questions. Examples of STEM-related subjects in the secondary school curriculum are Biology, Chemistry, Physics, Science, Mathematics and Additional Mathematics.

Meanwhile, all the items in the survey form had a fourpoint Likert scale response option, namely strongly disagree, disagree, agree and strongly agree. The students' responses to each item received weighted value from 1 (strongly disagree) to 4 (strongly agree).

Table 2 Modules designed and their description

\begin{tabular}{|c|c|}
\hline Module Title & Materials and Description \\
\hline Algebraic Expression & $\begin{array}{l}\text { - By using 'Sticky Tiles' is one of the easy-to-understand and practised } \\
\text { learning patterns in a student's classroom. } \\
\text { - Integers and Algebraic Expressions are among the titles that can be } \\
\text { combined for learning using this method. }\end{array}$ \\
\hline Crystal Snowflakes & $\begin{array}{l}\text { - This experiment would form a snow-shaped crystal made from a chenille } \\
\text { craft stick. Crystals would form for a minimum of } 8 \text { hours until overnight } \\
\text { and require only a few ingredients. } \\
\text { The main ingredient in this experiment was Borax powder, a type of } \\
\text { compound applied as a catalyst for washing clothes }\end{array}$ \\
\hline Photosynthesis & $\begin{array}{l}\text { - To study the presence of starch in leaves as the presence of sunlight helps } \\
\text { plants in the process of photosynthesis and starch production. } \\
\text { - Use leaves, tissue paper, syrup and methanol }\end{array}$ \\
\hline Friction & $\begin{array}{l}\text { - Frictional force is the force produced when two surfaces come into contact } \\
\text { with each other and friction force is the force that opposes, stops, and } \\
\text { obstructs the movement of an object. } \\
\text { The friction force also prevents an object from moving and can cause the } \\
\text { movement of an object to slow down and eventually stop. }\end{array}$ \\
\hline Oobleck & $\begin{array}{l}\text { - Oobleck is a mixture that has fluid and solid properties depending on the } \\
\text { force applied to the Oobleck mixture. } \\
\text { - If the applied force is high, Oobleck would show solid properties. } \\
\text { Meanwhile, if the applied force is low, the liquid characteristics are shown } \\
\text { - Materials are corn flour, water and food colouring. }\end{array}$ \\
\hline Plant Reproduction & $\begin{array}{l}\text { - The aims are to communicate the structure and function of each part of the } \\
\text { flower, to learn the next flowering/flowering process for self-pollination } \\
\text { and clogging. }\end{array}$ \\
\hline
\end{tabular}


To enable all students to participate fully in the program, six (6) stations were set up and the students were also divided into six (6) small groups. The program has focused on school-based learning systems such as photosynthesis, friction force, plant reproduction systems and more. Before the students are departed into their group, the students were given questions with a time limit to test their understanding before joining the STEM program.

Then, the students were given information regarding the module involved in the station. The facilitator would give live instruction and let the student engage in a hands-on activity in the module. Before the group departed to the next station, they would again be tested with five (5) questions from each station to elicit their optimum level of understanding after the module

\section{RESULT AND FINDING}

The effectiveness of the program is shown through the feedback survey forms. The feedback survey form is divided into three important elements. There are; (A) the program's aim and objectives, (B) the program's management, (C) the student's perspectives for the program's effectiveness. All these criteria are important to ensure the program's effectiveness while upgrading the activities in the future. Table 3 shows the details elements in the feedback forms meanwhile the survey results are presented in Figure 2.

Table 3 The detail elements asses for the program

\begin{tabular}{|c|c|}
\hline Code & Assessment \\
\hline \multicolumn{2}{|r|}{ A: Program } \\
\hline A1 & $\begin{array}{l}\text { The objective of this program is to provide exposure to Science, Technology, Engineering and } \\
\text { Mathematics (STEM). }\end{array}$ \\
\hline A2 & The content of the program is in line with school learning. \\
\hline A3 & The activity of each station is effectively managed. \\
\hline A4 & Use of effective teaching aids / experimental materials. \\
\hline A5 & Deliverable and effective facilitator. \\
\hline \multicolumn{2}{|r|}{ B: Program Management } \\
\hline B1 & The program execution journey went smoothly \\
\hline B2 & The time allocated for each station is appropriate. \\
\hline \multicolumn{2}{|r|}{ C: Program Effectiveness } \\
\hline $\mathrm{C} 1$ & $\begin{array}{l}\text { My understanding of Science, Technology, Engineering and Mathematics (STEM) has } \\
\text { improved since before joining the program. }\end{array}$ \\
\hline $\mathrm{C} 2$ & After this program I can apply the knowledge learned. \\
\hline $\mathrm{C} 3$ & I can tell about the knowledge learned throughout this program to my family and friends \\
\hline
\end{tabular}


C4 Overall the program was successful and rewarding.

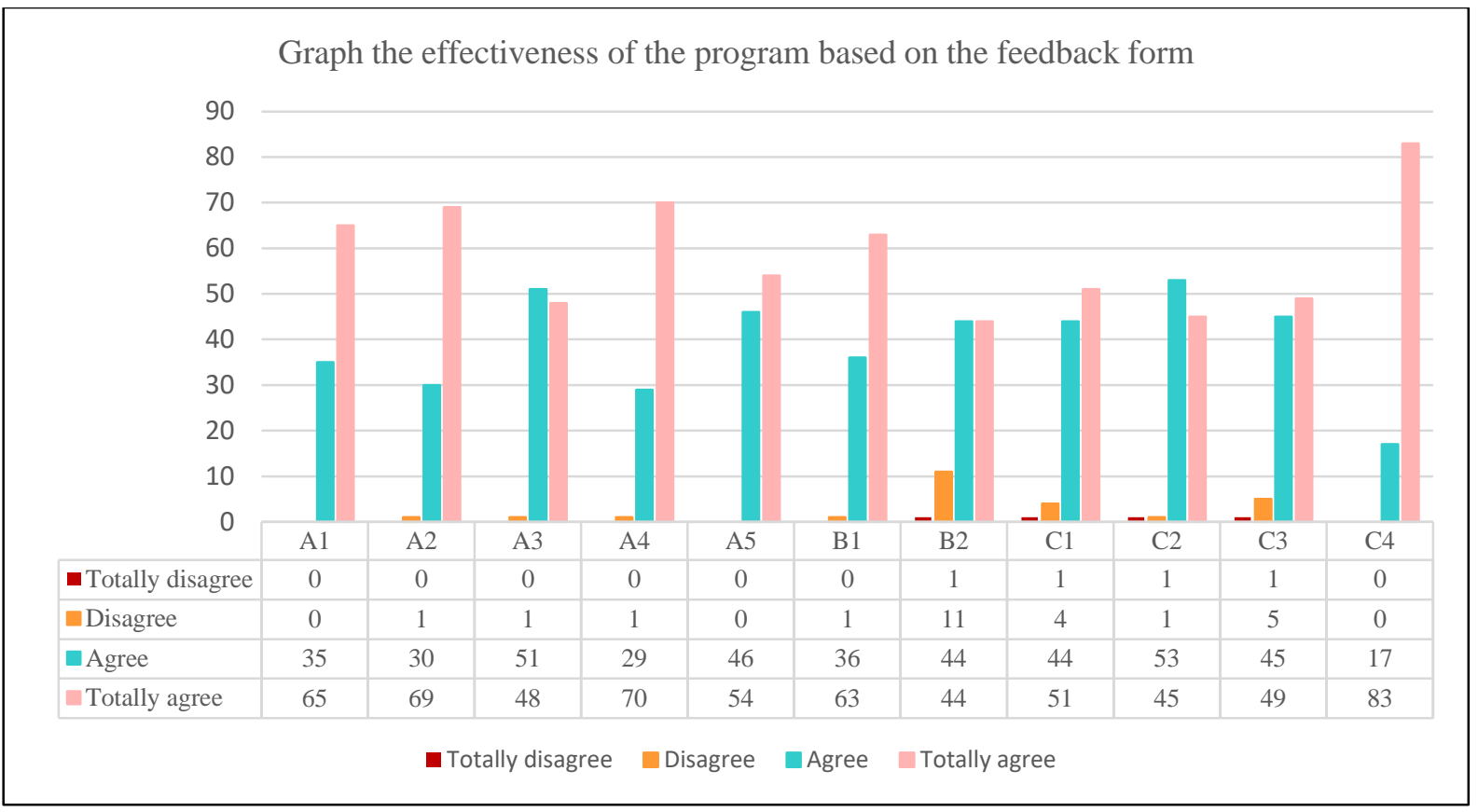

Figure 2. The result from feedback form

Based on the analysis, there were $88 \%$ to $100 \%$ of students' answers either 'Agree' or 'Totally Agree' towards all the elements in the feedback form. On the other hand, the remainder engaged in A2 (1\%), A3 (1\%), A4 (1\%), A5 (0\%), B1 (1\%), B2 (12\%), C1 (5\%), C2 (2\%), C3 (6\%) and $\mathrm{C} 4(0 \%)$. Even though the majority of students agree with the suitability of the modules presented in line with school learning, there was $1 \%$ 'Disagree' range in the A2 element. Therefore, some modules would brush up again to ensure that the modules are in the syllabus-based. In the meantime, $12 \%$ of students were disagreeing for each station's time allocation in the B2 element. During the event day, each group was given 15 minutes at each station and the students' needs to move to the next stations after the time's end. Thus, the total of students in each group and each station's activities has to be cogitated while allocating the time.

\section{CONCLUSION}

Throughout this study, more research regarding STEM is required to learn the altered approaches that connect employers with educators while bridging the gap between today's learners and tomorrow's careers.

Young Scientist Pioneer Program is a big program that not only involved activities among UTM students but also engagement between other university, schoolchildren and teachers. It has also been able to give new chances for UTM students not only to increase the knowledge about STEM but also enhance their communication, leadership and thinking skills. As a conclusion, the committee believes that connection with impact through collaboration is the challenging task but it is worth doing to come together to develop strategies that build, appeal and preserve a more diverse and sustainable STEM program. 


\section{ACKNOWLEDGMENT}

The authors would like to express their appreciation for the support of Kolej Datin Seri Endon, Universiti Teknologi Malaysia, Tourism Malaysia, SMK Wira Penrissen, Kota Samarahan, Sarawak, and Jabatan Pendidikan Negeri Johor for the program facilities and financial support.

\section{REFERENCES}

[1] Ashford, V. D. (2016). STEM after school programming: The effect on student achievement and attitude (Unpublished doctoral dissertation). Wingate University, Charlotte, NC.

[2] Bunyamin, Muhammad Abd Hadi. (2015). Pendidikan STEM Bersepadu: Perspektif Global, Perkembangan Semasa di Malaysia, dan Langkah Kehadapan. Buletin Persatuan Pendidikan Sains dan Matematik Johor. 25. 1-6.

[3] Connor, A. M., Karmokar, S., and Whittington, C. (2019). From STEM to STEAM: Strategies for Enhancing Engineering \& Technology Education. International Journal of Engineering Pedagogy (IJEP), 9(2), 137.

[4] Deloof, M. (2003). Does working capital management affect profitability of Belgian firms? Journal of business finance \& Accounting, 30(3-4), 573-588.

[5] Hom, E. (2014). What is STEM Education? Retrieved 4 September 2019, from https://www.livescience.com/43296-what-is-stemeducation.html

[6] Jayarajah, K., Saat, R. M., Rauf, A., \& Amnah, R. (2014). A Review of Science, Technology, Engineering $\&$ Mathematics (STEM) Education Research from 1999-2013: A Malaysian Perspective. Eurasia Journal of Mathematics, Science \& Technology Education, 10(3).

[7] Kementerian Pendidikan Malaysia (2013). Pelan Pembangunan Pendidikan Malaysia (2013). Retrieved from www.moe.gov.my

[8] Khalil, N. M., \& Osman, K. (2017). STEM 21CS Module: Fostering 21st century skills through integrated STEM. K-12 STEM Education, 3(3), 225233. Retrieved from http://smk.ukm.my/erep/fail3.cfm? komp=TGG2017804
[9] Meng, C. C., Idris, N., \& Eu, L. K. (2014).

Secondary Students' Perceptions of Assessments in Science, Technology, Engineering, and Mathematics (STEM). Eurasia Journal of Mathematics, Science \& Technology Education, 10(3).

[10] McCaslin, S. D. (2015). The influence of stem initiative programs for middle and high school students on female STEM college majors (Unpublished doctoral dissertation). Capella University, Minnesota, US

[11] Narayan, R., Park, S., Peker, D., Suh, J. (2013). Students' Images of Scientists and Doing Science: An International Comparison Study. Eurasia Journal of Mathematics, Science \& Technology Education, 9(2), 115-129.

[12] Osman, K., Hiong, L. C., \& Vebrianto, R. (2013). 21 st Century Biology: An Interdisciplinary Approach of Biology, Technology, Engineering and Mathematics Education. Procedia-Social and Behavioral Sciences, 102, 188-194.

[13] Wilhelm, J. (2014). Project-based instruction with future STEM educators: An interdisciplinary approach. Journal of College Science Teaching, 43(4), 80-90. Retrieved from http://www.jstor.org/stable/43632018 